\title{
BIODYNAMIC AGRICULTURE - OLD TRADITIONS AND MODERN PRACTICES
}

\author{
R. Beluhova-Uzunova*, D. Atanasov \\ Department of Economics, Agricultural University - Plovdiv, Plovdiv, Bulgaria
}

\begin{abstract}
The concerns regarding food security and safety, environmental challenges and resource scarcity remodel the prospects of agriculture. Therefore biodynamic farming as an alternative method for sustainable production becomes an object of growing scientific interest in the past 20 years. Biodynamic farming is one of the oldest organic systems and its roots could be found in the beginning of $20^{\text {th }}$ century. Although the skepticism, biodynamic agriculture evolved over the years and nowadays is considered as an opportunity to address various environmental, social and economic issues. The aim of the paper is to introduce the concept and features of biodynamic agriculture and observe different case studies and surveys on the effect of this farming system upon yields, profitability and sustainability. The analysis is based on different research methods. The paper applies monographic, historical and comparative methods. The results indicate that biodynamic farms have higher soil quality, lower crop yields, and equal or greater net returns than conventional agricultural holdings. The long-term effect of biodynamic farming on the economic performance, however, needs further research and investigation. The studies prove that biodynamic agriculture is important alternative farming system that could provide answers to number of alarming questions associated with viability and sustainable development.
\end{abstract}

Key words: sustainability, alternative farming system, soil quality

\section{INTRODUCTION}

The concerns regarding food security and safety, environmental challenges and resource scarcity remodel the prospects of agriculture. Therefore biodynamic farming as an alternative method for sustainable production becomes an object of scientific interest in the past 20 years. Biodynamic agriculture is one of the oldest concepts, which roots could be found in Rudolf Steiner lectures from at Schloss Koberwitz (1924). This farming method evolved over the years and the number of biodynamic farms and operations is increasing in parallel with the challenges related to agriculture. Biodynamic farming could help in addressing these issues, maintaining biodiversity and providing sustainability.

Correspondence to: Rositsa Beluhova-Uzunova, Department of Economics, Agricultural University - Plovdiv, 12 Medeleev Bld., 4000 Plovdiv,

Bulgaria,0883326543, e-mail:

rosicab_uzunova@abv.bg
The aim of the paper is to present an overview on different studies and case trails compering biodynamic, organic and conventional agriculture, to analyze the economic and environmental effect of biodynamic farming and highlight prospects and opportunities for the development of this alternative method.

The first part of the paper outlines the material, methods of the survey and theoretical background on the concept of biodynamic farming. The second part focuses on the case trails and economic benefits of biodynamic agriculture. In the third part are analyzed the opportunities for development of this sustainable method in Bulgaria.

\section{MATERIALS AND METHODS}

The paper applies monographic, historical and comparative methods of analysis. Unstructured interviews with farmers are concluded in order to analyze the opportunities for biodynamic farming development in Bulgaria. The form of the unstructured interview varies widely, with 
some questions being prepared in advance in relation to a topic. (1).

The data related to the trends in biodynamic farming is provided by Demeter International as the largest certification organization for biodynamic agriculture.

\section{THEORETICAL BACKGROUND}

In 1924 Rudolf Steiner presented the concept of biodynamic farming with a series of lectures. Based on the course "Spiritual Foundations for the Renewal of Agriculture" $(2,3)$, he defined the main principles of this alternative method. Rudolf Steiner believed that the modernization was replacing critical implicit knowledge that had been instinctually refined by farmers for centuries. (4). He was concerned with the introduction of chemical fertilizer and focused on development of unique preparations. Steiner considered the farm as a living organism and concentrate on the opportunities for healing the planet. Ehrenfried Pfeiffer, who worked with Steiner, developed these ideas in the United States in the 1930s. Although Rudolf Steiner is the "originator" of bio-dynamic agriculture, the term "bio-dynamic" was introduced in Pfeiffer's publications: Practical Guide to the Use of the Bio-Dynamic Preparations and Biodynamic Farming and Gardening (5).

In 1928 the first Demeter Symbol was established, and the first standards for Demeter quality control formulated. In 1985 Demeter was formed in the USA, seventeen years before the establishment of the National Organic Program. Demeter International is the first, and remains, the only association consisting of a network of individual
BELUHOVA-UZUNOVA R., et al. certification organizations in biodynamic farming. (6)

During the 50`s Maria Thun tested Rudolf Steiner's concept in her farm and in 1962 she created annual planting calendar and summarized her methods in Gardening for life: The biodynamic way. (7)

In 1997 nineteen Demeter Organizations created Demeter International seeking cooperation among counties and further development of biodynamic farming. In 2002 the International Biodynamic Association (IBDA) is established aimed to protect the trademark "Demeter" and "Biodynamic". The International Biodynamic Council (IBDC) is founded in 2012.

In 2019 Demeter Organization has 19 full members, with an independent Demeter certification program, as well as 4 guest members. The biodynamic farming is presented by 5595 farms with 187860 ha in 55 countries. (6)

\section{TRENDS IN BIODYNAMIC FARMING}

Biodynamic farming is considered "beyond organic" $(4,8)$. The main differences between the two methods are related to the unique preparation applied in the biodynamic agriculture. The emerging concept of biodynamic farming is gaining popularity all over the world although the number of farms, operator and distributors is far below the results presented by organic agriculture.

The development of biodynamic farming is illustrated in Figure 1 and Table 1. They represent the trends over the past 18 years and the number of operations in 2019 in Demeter International members and other selected countries.

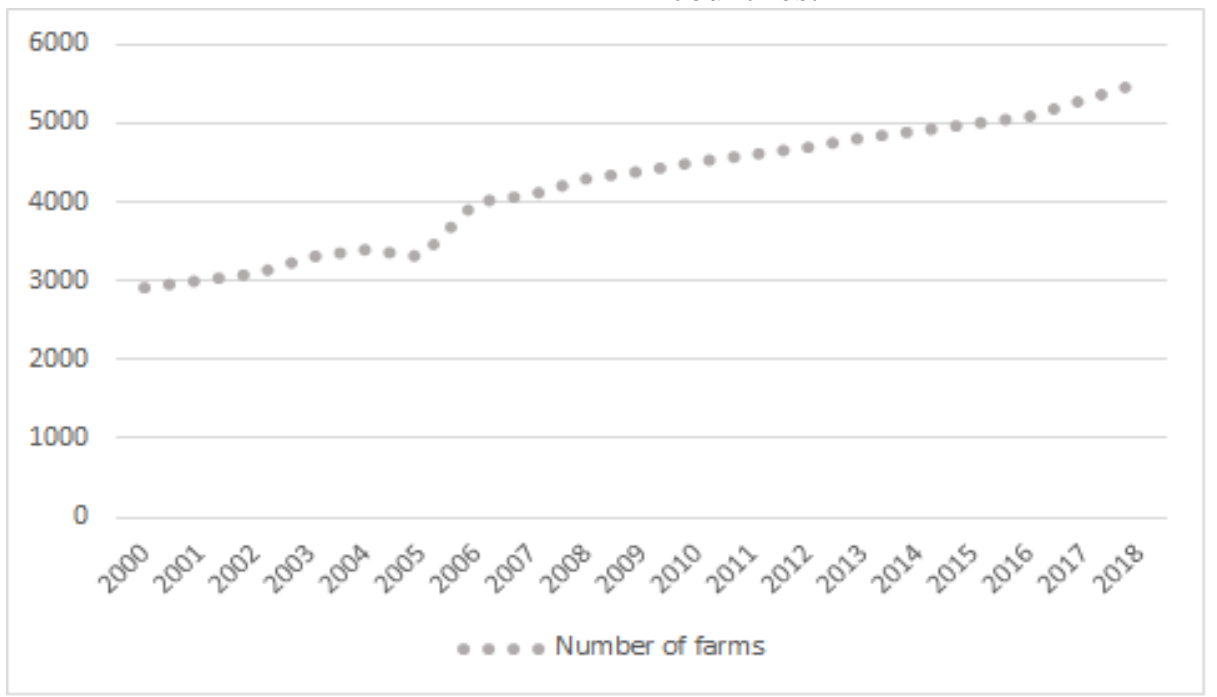

Figure 1. Number of Demeter certified farms, 2000-2018

Source: Demeter International 
Table 1. Certified Demeter operations (2019, number)

\begin{tabular}{|l|l|l|l|l|}
\hline Countries & Hectares & Farms & Processors & Distributors \\
\hline Austria & 5.720 & 186 & 35 & 10 \\
\hline Brazil & 1.004 & 27 & 25 & 6 \\
\hline Denmark & 2.384 & 33 & 9 & 8 \\
\hline Egypt & 2.839 & 60 & 8 & 6 \\
\hline Finland & 404 & 17 & 5 & 4 \\
\hline France & 13.665 & 511 & 108 & 42 \\
\hline Germany & 85.395 & 1552 & 403 & 124 \\
\hline Great Britain & 3.734 & 100 & 43 & 13 \\
\hline India & 5.417 & 403 & 5 & 1 \\
\hline Italy & 9.640 & 286 & 51 & 43 \\
\hline Luxembourg & 530 & 13 & 3 & 2 \\
\hline The Netherlands & 6.337 & 136 & 42 & 26 \\
\hline New Zealand & 336 & 21 & 3 & 1 \\
\hline Norway & 685 & 23 & 9 & 3 \\
\hline Slovenia & 216 & 33 & 3 & 1 \\
\hline Spain & 6.243 & 133 & 27 & 12 \\
\hline Sweden & 859 & 16 & 6 & 8 \\
\hline Switzerland & 5.556 & 255 & 63 & 54 \\
\hline USA & 9.001 & 118 & 88 & 36 \\
\hline Argentina & 1.164 & 36 & 6 & 1 \\
\hline Bulgaria & 0 & 0 & 0 & 1 \\
\hline Chile & 1.379 & 22 & 0 & 3 \\
\hline Czech Republic & 3.541 & 5 & 0 & 1 \\
\hline Hungary & 6.319 & 26 & 1 & 2 \\
\hline Lithuania & 1.389 & 11 & 0 & 1 \\
\hline Poland & 3.520 & 13 & 0 & 0 \\
\hline Turkey & 1.102 & 153 & 1 & 2 \\
\hline Sour: Den & \\
\hline
\end{tabular}

Source: Demeter International

The data shows steady growth over the past eighteen years - the number of farms increased by more than $47 \%$. Some variations are observed between 2004 and 2007, where the number of farms increased significantly. The growth is related to the foundation of International Biodynamic Association and Council and the raising concerns related to sustainability and biodiversity.

The number of countries with DemeterInternational certified biodynamic activity increased from 42 to 55 . For the period Slovenia and Spain became members of Demeter International. In Bulgaria there is not a certified biodynamic farm, but there is a registered biodynamic distributor. The three leading countries, based on biodynamic hectares, are Germany (up 22\% compare to 2012), Italy (up 10\%). In France the trends show substantial growth by over $40 \%$ for the period 2012-2019. These results in France are associated with the development of biodynamic wine sector. A significant growth also is observed in Spain (65\%) and is related to sectors like vegetables, viniculture and wine.

Germany has the most biodynamic farms, the most biodynamic processors, and the most biodynamic distributors. Germany, France, Italy and Spain are the leading countries in the sector.

Demeter-International reports the figures from all the biodynamic farms covered by their own certification. This underestimates the total world biodynamic activity since some countries, for example Australia, are not covered by Demeter-International certification, and some biodynamic farmers are certified 
"organic" (rather than "biodynamic") while some others are not certified at all (9).

It should be noted that some farms prefer to be certified only as organic although they grow crops in biodynamic way. The subsidies under the Common Agricultural Policy stimulate the rapid growth of organic farming.

\section{BASIC EXPERIMENTS, CASE TRIALS AND ECONOMIC STUDIES}

\section{Case trials}

The unique preparations are the main features of biodynamic farming. Rudolf Steiner introduced the practice of making preparations based on cow manure, silica, and a variety of herbal plants. Steiner's fertilization methodology also uses processes that reflect mystical and superstitious elements (10).

These unique preparations were subject of various experiments. In the beginning the case trials aim to present the new methods without verification. Between 1950s and 1960s Steiner followers made a numerous comparative trials, often without any replication, in order to analyze the general effects of the preparation (11).In the 1970s the preparations were tested by diploma and degree students. In 1979 the Biodynamic Research Institute in Darmstadt developed a long-term program of research into the preparations in partnership with some universities. The important results have been published in a document entitled "Ergebnisse aus der Präparate forschung" (12). The next yeas some authors published short term trials on the effect of preparation on soil quality and biology (13-16). Besides these case trials, four basic experiments were carried out. The experiments in Germany (17-20), and Switzerland (21-23) and one 32- year old experiment in Sweden (24). They compared conventional, organic, and biodynamic methods or different combinations. The results of the case trials show the positive effect of biodynamic farming in several directions. The biodynamic farming results higher soil organic matter $(25,26)$ and more efficient use of nitrogen supplied in biodynamic system (22). On the other hand, biodynamic farming affects the diversity of micro flora more clearly and various scientists have come to similar conclusions on the basis of long-term trials. (27)

Examination of 28 different experiments in Germany showed that the use of the biodynamic sprays increased crop yields on years where yields were low (17). This so called "yield-balancing" effect could possibly be important for risk management. These regulators show hormone-like effects on various crops grown in several studies (28-30). In 2015 a project related to biodynamic preparation was carried out. The survey includes case studies and determined that every farm has unique features and the results could vary among farmers and sectors. (11)

\section{Economic studies}

Although the biodynamic preparations are object of growing interest, this alternative methods is not gaining much attention in the circles of agricultural economist. $(8,31)$. Some studies are conducted in Germany, Austria, New Zeeland, the Netherlands and the Czech Republic.

Schlüter (32) analysed yields and profitability of 16 biodynamic farms in seven production regions in Baden Württemberg. The study compares the results with statistics from the Ministry of Agriculture in Germany. The yields of all the cereal crops in biodynamic farms were lower and the average were almost equal to conventional farm yields on the good soils and considerably lower on the poorer soils. Milk productivity in biodynamic farms was almost $15 \%$ lower compare to the conventional farms. The biodynamic and conventional farms had similar gross revenues. (33). However, because the biodynamic farmers had lower costs than the conventional farmers, their profits were higher. Koepf (34) and Lampkin (35) registered similar results regarding the economic performance of biodynamic farms.

In the Netherlands (36) a survey was carried out on 72 ha experimental farm. The results showed that gross revenue was the highest for the biodynamic farm because of the high premiums paid for the biodynamic products. The total production costs also were higher and biodynamic farm had the lowest net income. Lampkin however considered that the results of the survey could be different by using less labour intensive farming system. (35)

In Germany, a study reported that yields of all vegetable crops for a six year period were lower on biodynamic plots compare to conventional plots (37). The prices for biodynamic products however were higher, which led to greater profits for most of biodynamic vegetables.

Reganold et al. (26) investigated soil quality and economic performance of biodynamic and 
conventional farms. The study examined annual accounts for the period 1987-1991. This data was compared to the reports by the Ministry of Agriculture and Fisheries in New Zealand. The biodynamic and conventional farms had similar profitability. Majority of the biodynamic products were sold as certified organic or biodynamic at premium prices up to $25 \%$ above the market prices of conventional products. Most of the biodynamic farms had less year-to-year variability in gross revenue than the conventional farms which is important for economic aspects of sustainability. (26)

In the Czech Republic several studies analysed the technical efficiency and economic performance of biodynamic, organic and conventional farms. (38-40). The results of the studies registered substantial difference between biodynamic and organic farms, except the subsidies. In general, conventional farms had the highest costs, revenues and gross added value. Based on the economic efficiency indicator, organic farms were the most efficient, followed by conventional farms, while biodynamic farms were inefficient. The number of farms' sample was low, especially the biodynamic farms (only 3 certificated farms). Therefore the results could not be representative and further research is recommended.

The economic studies showed that biodynamic farming systems could reach profitability closer to organic and conventional farms. Many biodynamic farmers still exist because of the price premium received for their products. Although the studies included these premiums, they did not count the environmental and health costs, which are external. When these external costs are included in the costs of production, the profitability and benefits to society have been shown to be the greater for some alternative farming systems (41)

\section{OPPORTUNITIES FOR BIODYNAMIC FARMING IN BULGARIA}

In Bulgaria the biodynamic farming is still developing concept. By contrast, organic agriculture is raising and for the period 20092016 the number of operators has increased by more than 15 times, which is the most significant growth in the EU-28. Major role for this increase plays the direct and green payments under Pillar 1 and the financial support under Pillar II.

In Bulgaria there is not a Biodynamic organization which is an obstacle for this alternative method. On the other hand, consumers are not familiar with the concepts compare to the interest in organic products. It is easier and more profitable to certify organic farm, although some of the organic farms grow crops in biodynamic way.

In Bulgaria some authors investigate the concept and features of biodynamic farming (42-44), but the papers are theoretical and do not present case-studies or any economic assessment. In 2013 the Institute of Agriculture in Karnobat conducted phytosanitary monitoring in a non-certified experimental biodynamic field of 2 hectares, growing cereals after pea as predecessor. The results compared with cereals grown under organic and conventional farming conditions (45).

In unstructured interviews, we interview two farmers which grow crops in biodynamic way although they are not certified. The holdings are small and specialized in vegetables, fruits and herbs. According to the farmers the popularity of organic agriculture has grown significantly in past decades and biodynamic farming is lagging behind. Biodynamic farmers face challenges with lower yields, more labour costs, less support, and difficulty of implementing biodynamic techniques. The farmers, however consider that there is difference between organic and biodynamic agriculture and the biodynamic production has better quality and maintain biodiversity. Although the social benefits, the interviewed farmers are certified as an organic producers, but hope to change consumer perception towards biodynamic farming and gain popularity.

Biodynamic agriculture could be an answer to the emerging challenges as climate change and food safety. The case studies conducted in different countries showed that biodynamic agriculture is a real alternative to the conventional farms. The biodynamic holdings could be as profitable as the conventional farms. Therefore agricultural policy could be directed to these holding and the development of biodynamic method should be stimulated.

\section{ACKNOWLEDGMENTS}

This paper was supported by the Bulgarian Ministry of Education and Science under the National Research Program "Healthy Foods for a Strong Bio-Economy and Quality of Life" approved by DCM \# 577 / 17.08.2018. 


\section{REFERENCES}

1. Bailey, K., Methods of Social Research (4. Ed.). Free Press. p. 194, 2008

2. Steiner, R., Agriculture Course Printed for private circulation only. Dornach, Switzerland: Goetheanum, 17-18, 1924 a.

3. Steiner, R., Report to members of the Anthroposophical Society after the Agriculture Course. Dornach, Switzerland, June 20, (C. E. Creeger \& M. Gardner, Trans.). In: Gardner, M., Spiritual Foundations for the Renewal of Agriculture by Rudolf Steiner (1993, pp. 112), $1924 \mathrm{~b}$.

4. Caldwell, A. Biodynamic Farming: Sustainable Solution https://fairfoodforall.wordpress.com/, 2012.

5. Pfeiffer, E., Bio-Dynamic Farming and Gardening: Soil Fertility Renewal and Preservation (F. Heckel, Trans.), New York: Anthroposophic Press. 938.

6. Demeter International, https://www.demeter.net/, Accession date 16.06.2019.

7. Thun, M., Gardening for Life- The Biodynamic Way: A Practical Introduction to a New Art of Gardening, Sowing, Planting, Harvesting. Harrington Press, ISBN 13: 9781869890322,2000

8. Phillips, J. and Rodriguez, L., Beyond Organic: An Overview of Biodynamic Agriculture with Case Examples". Selected paper prepared for presentation at the American Agricultural Economics Association Annual Meeting, Long Beach, California, and July 23 - 26, 2006.

9. Paull, J., Biodynamic agriculture shows steady global growth, http://orgprints.org/26246/13/26246.pdf, 2013.

10. Conkin, P., A Revolution Down on the Farm. Lexington: University Press of Kentucky, pp. 51, 2008.

11. Sedlmayr, A., et.al, The biodynamic preparations in context: Individual approaches to preparation work - Case studies of worldwide practice. Sektion für Landwirtschaft am Goetheanum, 2016.

12. Koenig, U., Ergebnisse aus der Präparateforschung. Schriftenreihe Inst. f. biol.-dyn. Forschung, Bd. 12, Darmstadt, 1999.

13. Carpenter-Boggs, L., Kennedy, A., Reganold, J., Organic and biodynamic management: effects on soil biology, Soil Science Society of America Journal 64:1651-1659, 2000.
14. Carpenter-Boggs, L., Reganold, J., Kennedy, A., Effects of biodynamic preparations on compost development, Biological Agriculture and Horticulture 17:313-328, 2000.

15. Ryan, M. and Ash, J., Effects of phosphorus and nitrogen on growth of pasture plants and VAM fungi in SE Australian soils with contrasting fertilizer histories (conventional and biodynamic). Agriculture, Ecosystems and Environment, 73:51-62. , 1996.

16. Zaller, J., Seed germination of the weed Rumex obtusifolius after on-farm conventional, biodynamic and vermicomposting of cattle manure. Annals of Applied Biology, 151:245-249, 2007.

17. Raupp, J. and König, U., Biodynamic preparations cause opposite yield effects depending upon yield levels, Biological Agriculture and Horticulture, 13:175-188, 1996.

18. Raupp J and Oltmanns M. Soil properties, crop yield and quality with farmyard manure with and without biodynamic preparations and with inorganic fertilizers. In: Long Term Field Experiments in Organic Farming, Raupp J, Pekrun C, Oltmanns M, Köpke U, editors. ISOFAR Scientific Series No 1. Verlag Dr. Köster, Berlin, Germany, 135-156, 2006.

19. Raupp J., Biodynamic approaches in research and development. In: Research Methodologies in Organic Farming, Ed: Zanoli R, Krell,R., REU Technical Series 58, FiBL, FAO, Rome; 1999

20. Zaller, J. and Kopke, U., Effects of traditional and biodynamic farmyard manure amendment on yields, soil chemical, biochemical and biological properties in a long-term field experiment. Biology and Fertility of Soils 40:222-229, 2004.

21. Berner, A., et.al, Crop yield and soil fertility response to reduced tillage under organic management. Soil Tillage Research 101:89-96, 2008.

22. Fliessbach et.al. Soil organic matter and biological soil quality indicators after 21 years of organic and conventional farming, Agriculture: Ecosystems and Environment 118:273-284, 2007.

23. Pfiffner, L. and Mader, P., Effects of biodynamic organic and conventional production systems on earthworm populations. Biological Agriculture and Horticulture, 5:3-10, 1997. 
24. Pettersson, B., Reents H., Wiestinghausen E., Dungkung Nordisk Forskningsring. Meddelande nr. 34, Järna, Sweden, 1992.

25. Droogers, P. and Bouma, J., Biodynamic vs Conventional farming effects on soil structure expressed by simulated potential productivity, Soil Science Society of America, 2006.

26. Reganold, J. et.al. Soil quality and financial performance on biodynamic and conventional farms in New Zealand. Science, 260:344-349, 1993.

27. Mader, P. et.al, Soil fertility and biodiversity in organic farming. Science, 296:1694-1697, 2002.

28. Fritz, J. P. et al., Basic research on the crop growth substance horn-silica, Rheinischenm, Friedrich Wilhelm University, Bonn, Germany, pp231-237, 1997.

29. Goldstein, W., A report on previous work done with biodynamic preparations. Biodynamics 129:1-10, 1979.

30. Goldstein, W. and Koepf, H., A contribution to the development of tests for biodynamic preparations. Elemente der Naturwissenschaft, 36:41-53, 1982.

31. Turinek, M. et al., Biodynamic agriculture research progress and priorities. Renewable Agriculture and Food Systems 24, pp. 146-154, 2009

32. Schlüter, C., Arbeits und betriebswirtschaftliche Verhältnisse in Betrieben des alternative Landbaus (Labor and economic relations on alternative farms.). Verlag E. Ulmer, Stuttgart, Germany, 1985.

33. Koepf, H., Organization, economic performance and labor requirements on biodynamic farms, Star and Furrow, 66:25-37, 1986.

34. Koepf, H., the Biodynamic Farm. Anthroposophic Press, Hudson, New York, 1989

35. Lampkin, N., Organic Farming. Farming Press Books, Ipswich, Great Britain levels, Biol. Agric. \& Hort. 13, 175-188, 1990.

36. Vereijken, P., Research on integrated arable farming and organic mixed farming
BELUHOVA-UZUNOVA R., et al.

in the Netherlands. Schweizerische Landwirtschaftliche Forschung, 29:2492564, 1990.

37. Reinken, G., Six years of biodynamic growing of vegetables and apples in comparison with the conventional farm management. In: H. Vogtmann, E. Boehneke and I. Fricke (eds). The Importance of Biological Agriculture in a World of Diminishing Resources. Verlagsgruppe Witzenhausen, Witzenhausen, Germany, pp.161-174, 1986.

38. Naglova, Z. and Vlasicova, E, Economic Performance of Conventional, Organic, and Biodynamic Farms J. Agr. Sci. Tech., Vol. 18: 881-894, 2016.

39. Pechrova, M., Efficiency of Biodynamic Farms. Agrarian Perspectives XXII, Development Trends in Agribusiness. CULS Prague, pp. 55-69, 2013.

40. Pechrova, M. and Vlasicova, E., Technical Efficiency of Organic and Biodynamic Farms in the Czech Republic. Agris OnLine Pap. Econ. Inform 5: 143-152, 2013.

41. Holmes, B., Can sustainable farming win the battle of the bottom line? Science Journal 60:1552-1558, 1993.

42. Beluhova-Uzunova, R., and Atanasov, D., Biodynamic Farming Method for Sustainable Production of Quality Food. Bulgarian Journal of Agricultural Economics and Management, 62:3, pp.4048, 2017.

43. Vlahova, V. and Arabska, E., Biodynamic agriculture- eco-friendly agricultural practice. New knowledge Journal of Science, Vol. 4: 2, pp. 46-50, 2015a.

44. Vlahova, V. and Arabska, E., Biodynamic preparations- alternative in sustainable agricultural system, New knowledge Journal of Science, Vol. 4:3, pp. 73-77, $2015 b$.

45. Maneva et.al. Phytosanitary monitoring, soil and plant condition in newly converted to biodynamic field, Scientific works III Institute of agriculture, Karnobat, ISSN 1314-961X, 2014. 